\title{
Metal accumulation and apoptosis in the alimentary canal of Lumbricus terrestris as a metal biomarker
}

\author{
André Filipe Santos Amaral* \& Armindo dos Santos Rodrigues \\ Departamento de Biologia, Universidade dos Açores, APT 1422, PT-9501-855 Ponta Delgada, São Miguel, \\ Açores, Portugal; *Author for correspondence (E-mail: aamaral@notes.uac.pt)
}

Received 29 July 2004; accepted 10 January 2005; Published online: March 2005

Key words: apoptosis, chloragogenous tissue, intestinal epithelium, metals, biomarker

\begin{abstract}
The chloragogenous tissue and the intestinal epithelium of adult earthworms, Lumbricus terrestris, sampled from sites with and without volcanic activity in the Azores were submitted to hematoxylin/eosin staining, autometallography and TUNEL-test in order to quantify the radial thickness of both tissues, their relative abundance of metals and apoptosis levels. Metals were visualized, through light microscopy, as black silver deposits (BSD) mostly in the chloragogenous tissue. The lowest radial thickness values of both tissues were found in the active volcanic sites, as well as the highest BSD and apoptosis levels. The BSD extent in the chloragogenous tissue, semi-quantified by stereology, exhibited a positive correlation with the apoptosis levels and a negative one with the radial thickness of both tissues. Thus, the variation of the radial thickness of both tissues, but especially of the chloragogenous tissue, which could reflect different cellular turnover rates caused by exposure to metals, is suggested as a biomarker of effect for metal exposure in terrestrial worms inhabiting volcanic environments.
\end{abstract}

\section{Introduction}

Volcanic activity that can manifest through lava emissions, degassing soils and hydrothermal sources, is one of the main inputs of metals, such as $\mathrm{Al}, \mathrm{As}, \mathrm{Hg}, \mathrm{Pb}$, and $\mathrm{Zn}$, in the soils (Ferreira \& Oskarsson 1999; Kelepertsis et al. 2001). This enrichment in metals renders a high fertility to volcanic soils making volcanic regions densely inhabited and therefore important scenarios for the study of effects of metal pollution.

Previous studies have shown how earthworms are able to tolerate high concentrations of metals in the soil (Ireland 1977; Stürzenbaum et al. 1998; Langdon et al. 1999, 2001) and that the posterior alimentary duct is their main site of metal accumulation, where the chloragogenous tissue separating the absorptive epithelium from the coelom is a major metal sink (Fischer \& Molnar 1992;
Morgan et al. 2002). The chloragogenous tissue is composed of pedunculated cells and its main functions are (Jamieson 1992): (a) synthesis of hemoglobin; (b) homeostasis of cation composition in the blood and coelomic fluid; (c) maintenance of a balanced $\mathrm{pH}$ level; (d) storage of nutrients and waste; and (e) uptake and detoxification of toxic cations. Additionally to chloragogenous tissue, the intestinal epithelium also reveals a great ability for metal accumulation as Morgan et al. (2002) found in the oligochaete Dendrodrilus rubidus.

Metals cannot be degraded by biological organisms and therefore persist in these as well as in the environment. The determination of the toxicity of metals is difficult because of the complex nature of their interactions with biological systems. Furthermore, for living organisms many metals are vital elements since they play important 
roles in the control of gene transcription, redox reactions and oxygen transport. However, essential and non-essential metals may also be prejudicial causing mutagenic (Filipic \& Hei 2004; Hei \& Filipic 2004), carcinogenic (Waalkes 2003; Waisberg et al. 2003) and teratogenic (Calevro et al. 1998) effects, which may all be related to apoptosis (Krug 2002). For example, Cd induces disruption of DNA repair leading to mutations that together with increased cell proliferation and blocked apoptosis could result in tumor formation (Waalkes 2003; Waisberg et al. 2003; Hei \& Filipic 2004). Another example is $\mathrm{Zn}$ that has an optimal intracellular range above or below which internucleosomal DNA cleavage, chromatin condensation, and nuclear fragmentation are induced (Krug 2002).

Apoptosis, or programmed cell death, controls the number of cells for different types of organs or tissues and directs the morphological reorganization, avoiding mispatterning during development (Hwang et al. 2004). It subserves a general homeostatic function in regulating the size of cell populations under both normal and pathological conditions (Kerr 2002; Zhang \& Xu 2002), it is involved in cellular turnover in normal adult animals, it accounts for both normal involution and pathological atrophy of tissues, and it occurs spontaneously in malignant tumors (Kerr 2002). Apoptosis is also present in numerous biological processes like the embryogenesis, the lymphocytic selection within the thymus or the involution of the mammary gland after a lactation period (Seve et al. 2002), and it is a well-conserved mechanism throughout metazoan evolution (Hwang et al. 2004). Agents that cause necrosis may also trigger apoptosis (Kerr 2002), but unlike necrosis, apoptosis requires energy (Seve et al. 2002). Apoptosis by metals can be caused by (a) $\mathrm{Ca}^{2+}$ overload, (b) DNA-damaging species and an increase in p53, (c) direct mitochondrial alterations that are upstream of caspase activation, (d) the direct activation of caspases, and/or (e) early activation of death receptors (Krug 2002).

Fragmentation of DNA is a hallmark of apoptosis and besides several biochemical markers that typify programmed cell death, apoptosis is also characterized by morphological markers such as cell and nuclear shrinkage, chromatin condensation, apoptotic body formation followed by phagocytosis of the dying cells (Zhang \& Xu
2002), and possibly by morphological cell changes that could alter the feature of the affected tissues.

The capability of earthworms to efficiently retain and compartmentalize metals within tissues may be useful in understanding the basic mechanisms that allow the accumulation of high body burdens (Morgan \& Morgan 1989). One of the target tissues for metal accumulation is the chloragogenous tissue (Ireland \& Richards 1977; Morgan \& Morgan 1989; Morgan et al. 2002), which shows a strong plasticity in its morphology provoked by the buildup of high levels of bioavailable metals. Thus, the aim of this study is to investigate if the morphological alterations shown in the chloragogenous tissue and in the intestine epithelium of Lumbricus terrestris are related to metal-induced apoptosis.

\section{Materials and methods}

\section{Sampling stations}

The Azores archipelago is made up by nine islands and is located in the North Atlantic Ocean at the triple junction of Eurasian, African and North American plates, characterized by an intricate tectonic settlement, where the seismic and volcanic occurrences are common (Nunes et al. 1993). São Miguel and Santa Maria are the two most eastern islands of the Azores, and the later is the oldest of all nine. Located in São Miguel, which is the largest island $\left(757 \mathrm{~km}^{2}\right)$, Furnas is a rural parish inside a caldera complex that is considered one of the most active and dangerous volcanoes in the Azores archipelago (Guest et al. 1999). Santa Maria, which is one of the smallest islands $\left(92 \mathrm{~km}^{2}\right)$, is also rural however has no volcanic activity since ca. 3 M.y. ago (Feraud et al. 1984).

\section{Earthworms: collection}

Forty clitellate Lumbricus terrestris, divided by four groups, were collected in autumn/2002. Half of the groups were from two sites within Santa Maria, Feteiras de Baixo (GM) and Aeroporto (FM), and the other half was from two sites in Furnas, Poça da Beija (BM) and near Água Azeda (AM). Earthworms were transferred to the laboratory, where they were depurated of gut contents by maintenance on moistened paper, for $36 \mathrm{~h}$. 


\section{Histological processing}

The ten specimens of $L$. $t$. from each site were used for light microscopy morphometry, autometallography and apoptosis analysis. From each worm, a fresh piece, posterior to the clitellum, was fixed in neutral-buffered formaldehyde (Hopwood 1996), dehydrated in alcohol, cleared in methylbenzoate (overnight), rinsed in benzene, embedded in paraffin and sectioned at $7 \mu \mathrm{m}$ thickness for morphometry and autometallography and at $4 \mu \mathrm{m}$ thickness for TUNEL-test.

\section{Morphometry}

Sections were stained with hematoxylin and eosin (Martoja \& Martoja-Pierson 1970). To quantify the radial thickness of the chloragogenous tissue and intestinal epithelium, the first and the fifth sections of all individuals were used and both were theoretically divided into four regions each, meaning a total of eight measurements per individual. Measurements were made by a single observer using micrometric eyepieces.

\section{Autometallography}

First developed by Danscher (1984), the procedure employed to demonstrate metals in the tissue sections was autometallography, which is a histochemical technique based on principles of photography (Soto et al. 1998a). Paraffin sections were dewaxed in xylene, hydrated in ethanol-water mixtures and left in an oven at $37^{\circ} \mathrm{C}$ until completely dried. Tissues sections were covered with a photographic emulsion (Ilford Nuclear Emulsion L4) under safety light conditions. After drying for $30 \mathrm{~min}$ in total darkness, sections were rinsed in a developer bath $(1: 5, \mathrm{~b} / \mathrm{w}$ Ilford PQ Universal) for $15 \mathrm{~min}$, rinsed in a stop bath $(1 \%$ acetic acid) for $1 \mathrm{~min}$, and finally rinsed in a fixative bath $(1: 10, \mathrm{~b} / \mathrm{w}$ Ilford Hypam) for $10 \mathrm{~min}$ (Soto et al. 1998a). Metal ions were developed as black silver deposits (BSD).

\section{TUNEL-test}

The detection of apoptotic nuclei in the intestinal epithelium and in the chloragogenous tissue was performed using a FragEL ${ }^{\mathrm{TM}}$ kit (Oncogene, USA). Briefly, tissue sections were dewaxed and rehydrated. Sections were then washed in Trisbuffered saline and treated with $20 \mu \mathrm{g} / \mathrm{ml}$ proteinase $\mathrm{K}$ for $20 \mathrm{~min}$ at room temperature. Tissues were treated with $3 \% \mathrm{H}_{2} \mathrm{O}_{2}$ for 5 min to inactivate endogenous peroxidase, and their DNA was labeled at 3 / ends with biotin-dUTP by incubation with the reaction buffer containing terminal deoxynucleotidyl transferase enzyme for $90 \mathrm{~min}$ at $37^{\circ} \mathrm{C}$. The sections were further incubated with peroxidase streptavidin conjugate to detect biotinylated nucleotides for $30 \mathrm{~min}$ at room temperature. Diaminobenzidine reacted with the labeled samples to generate an insoluble colored substrate at the site of DNA fragmentation. Finally, sections were counterstained with methyl green to aid in the morphological evaluation and characterization of normal and apoptotic cells.

\section{Statistical analyses}

Radial thickness differences determined by morphometry in the earthworm chloragogenous tissue and intestinal epithelium from the four sites were examined by a one-way ANOVA, while the extent of BSD and apoptotic nuclei differences were examined by the Mann-Whitney test. Pearson correlations between variables, and both tests were determined using the statistical package SPSS 11.5 (SPSS Inc., Microsoft).

\section{Results}

Individuals of Santa Maria and Furnas differed significantly not only on the radial thickness of the intestinal epithelium but also on the radial thickness of the chloragogenous tissue, with the highest values in the former (Figures 1 and 2). One should note that the radial thickness of the chloragogenous tissue of the individuals of Santa Maria presented values four or five-fold higher than the ones of Furnas (Figure 2).

The individuals of Santa Maria and Furnas also differed significantly on the volumetric density of BSD found in the chloragogenous tissue. But now the highest levels of BSD extent were found in Furnas, which were approximately four-fold higher than the ones of Santa Maria (Figures 1 and 3).

After the application of the TUNEL-test, one observed that in the individuals of Santa Maria no nuclei were found apoptotic (Figure 4 and 5). 

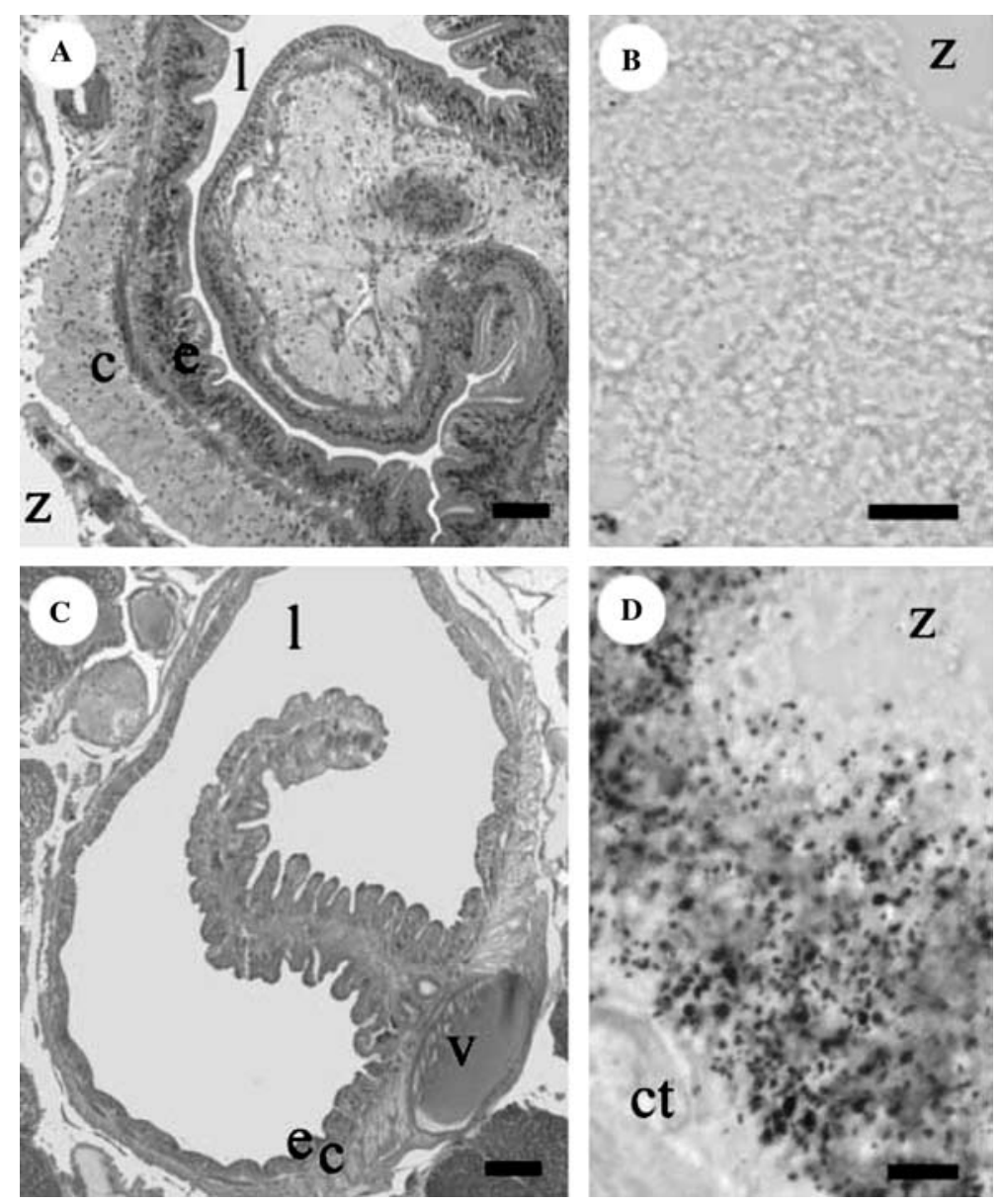

Figure 1. (a) Section of the intestine of a specimen from Santa Maria, stained with hematoxylin and eosin, showing high chloragogenous tissue and intestinal epithelium. Scale $b a r=100 \mu \mathrm{m}$. (b) Chloragogenous tissue of a specimen from Santa Maria, stained with autometallography, showing few BSD. Scale bar $=10 \mu \mathrm{m}$. (c) Section of the intestine of a specimen from Furnas, stained with hematoxylin and eosin, showing reduced chloragogenous tissue and intestinal epithelium. Scale bar $=100 \mu \mathrm{m}$. (d)- Chloragogenous tissue of a specimen from Furnas, stained with autometallography, showing many BSD. Scale bar $=5 \mu \mathrm{m}$. Chloragogenous tissue $=\mathrm{c}$; connective tissue $=\mathrm{ct}$; intestinal epithelium $=\mathrm{e}$; lumen $=1$; dorsal blood vessel $=\mathrm{v}$; coelomic space $=\mathrm{z}$.

However, in the individuals of Furnas both tissues studied, intestinal epithelium and chloragogenous tissue, presented apoptotic nuclei (Figures 4 and 5). Also, some coelomocytes presented apoptotic nuclei.

The radial thickness of the chloragogenous tissue was positively and significantly correlated with the radial thickness of the intestinal epithelium. Both were also negatively and significantly correlated with the BSD extent in the chloragogenous tissue and with the apoptotic nuclei of the same tissue. One found that the BSD extent was also correlated with the apoptotic nuclei of the chloragogenous tissue but not with the ones of the intestinal epithelium (Table 1).

\section{Discussion}

Volcanic soils, through natural volcanic activity, may be enriched in metals such as $\mathrm{Al}, \mathrm{As}, \mathrm{Hg}, \mathrm{Pb}$, and Zn (Ferreira \& Oskarsson 1999; Kelepertsis et al. 2001), rendering a source of these metals to living organisms that may accumulate them in different parts of their bodies. Autometallography has been formerly reported to be a valuable technique for the localization and quantification of $\mathrm{Cd}$, $\mathrm{Cu}, \mathrm{Zn}$, and $\mathrm{Hg}$ deposits in cellular compartments of marine and terrestrial animals (Hemelraad \& Herwig 1988; Holwerda 1991; Marigómez et al. 1996; Soto et al. 1996, 1998b). In the present study, metals weakly bound to proteins were readily 


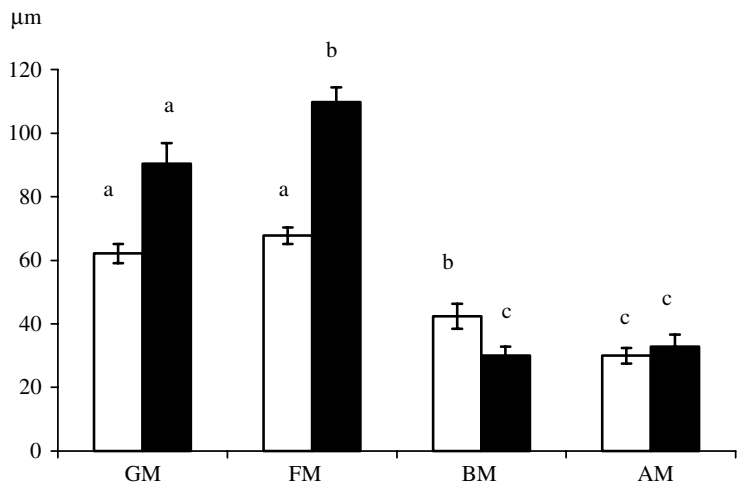

Figure 2. Radial thickness $[\bar{x} \pm \mathrm{se}](\mu \mathrm{m})$ of the intestinal epithelium (white bars) and chloragogenous tissue (black bars) of L. $t$. from Santa Maria (GM and FM) and Furnas (BM and AM). Different letters over the bars indicate significant differences at $P \leq 0.05$.

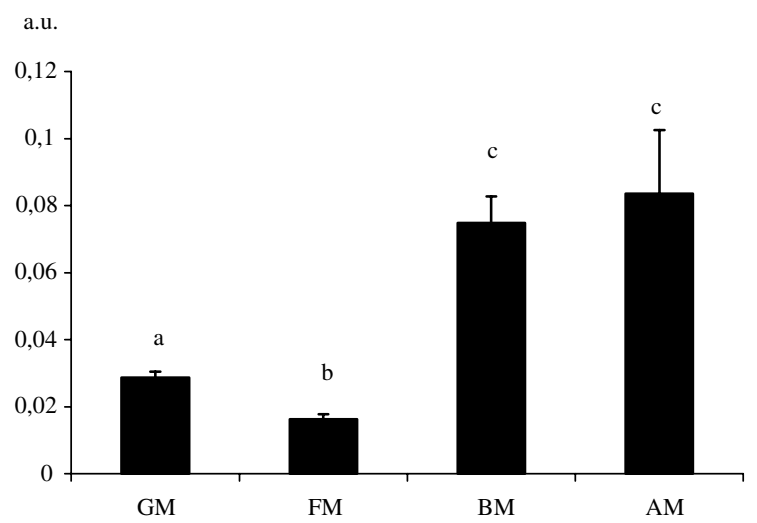

Figure 3. (Semi)quantification, by means of volume density, of metals $\left(V_{\mathrm{v}_{\mathrm{BSD}}}\right)[\overline{\mathrm{X}} \pm \mathrm{se}]$ in the chloragogenous tissue of $L . t$. from Santa Maria (GM and FM) and Furnas (BM and AM). a. u. $=$ arbitrary units. Different letters over the bars indicate significant differences at $P \leq 0.05$.
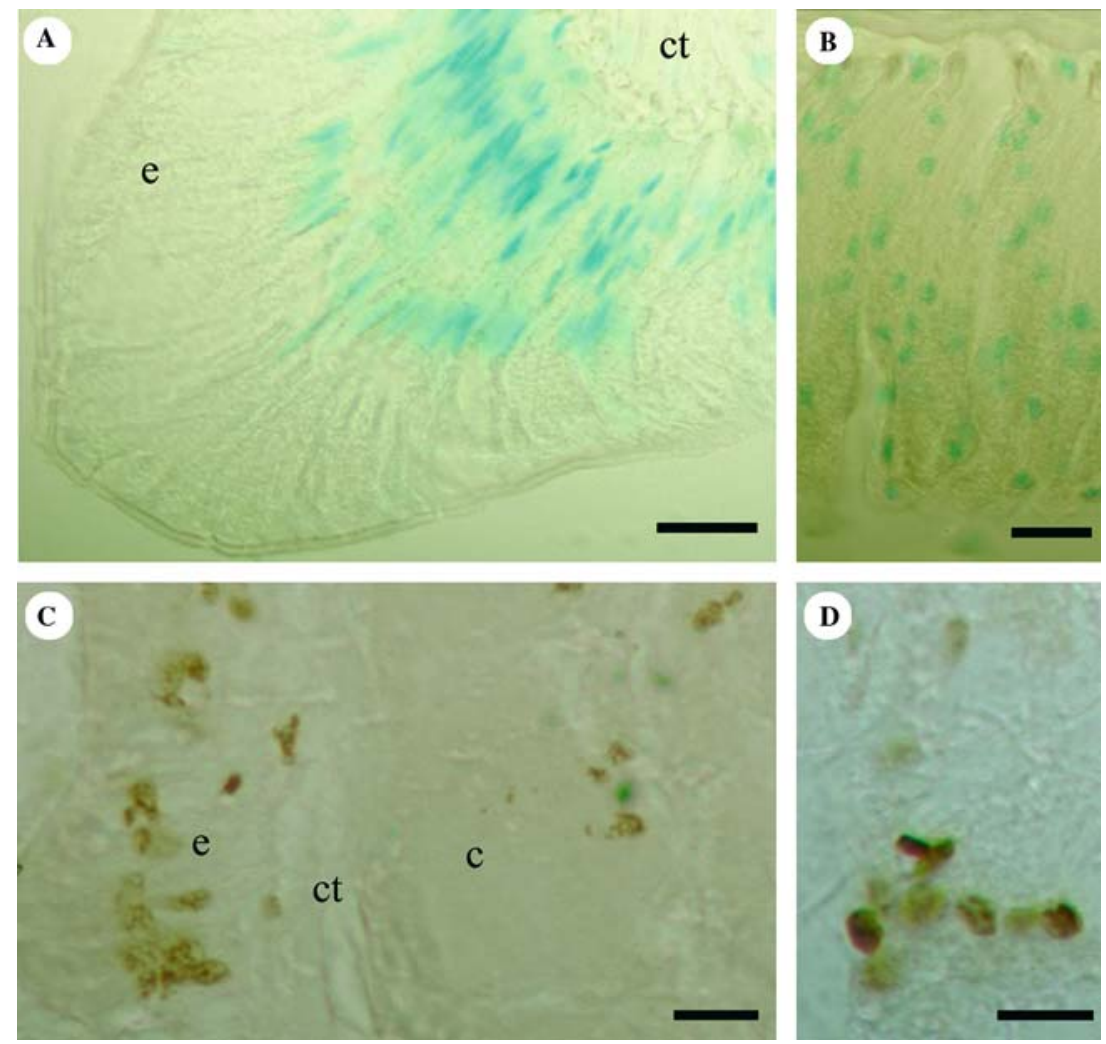

Figure 4. (a) Intestinal epithelium of a specimen from Santa Maria, stained with TUNEL-test, showing no apoptotic nuclei. Scale bar $=20 \mu \mathrm{m}$. (b) Chloragogenous tissue of a specimen from Santa Maria, stained with TUNEL-test, showing no apoptotic nuclei. Scale bar $=20 \mu \mathrm{m}$. (c) Intestinal epithelium and chloragogenous tissue in the tiflosole of a specimen from Furnas, stained with TUNEL-test, showing several apoptotic nuclei. Scale bar $=10 \mu \mathrm{m}$. (d) Chloragogenous tissue of a specimen from Furnas, stained with TUNEL-test, showing apoptotic nuclei. Scale bar $=10 \mu \mathrm{m}$. Chloragogenous tissue $=\mathrm{c}$; connective tissue $=\mathrm{ct}$; intestinal epithelium $=\mathrm{e}$. 


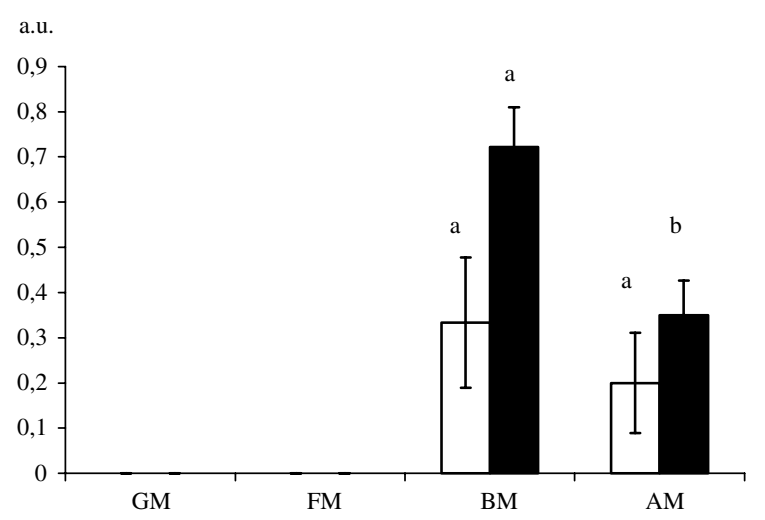

Figure 5. (Semi)quantification of apoptotic nuclei $[\bar{x} \pm$ se $]$ of the intestinal epithelium (white bars) and chloragogenous tissue (black bars) of L. t. from Santa Maria (GM and FM) and Furnas (BM and AM). a. u. = arbitrary units. Different letters over the bars indicate significant differences at $P \leq 0.05$.

Table 1. Pearson's correlation between radial thickness of the chloragogenous tissue (RTC), radial thickness of the intestinal epithelium (RTIE), apoptotic nuclei of the chloragogenous tissue (ANC), apoptotic nuclei of the intestinal epithelium (ANIE), and black silver deposits (BSD) found in the chloragogenous tissue.

\begin{tabular}{llllll}
\hline & RTC & RTIE & ANC & ANIE & BSD \\
\hline RTC & - & & & & \\
RTIE & $0.843^{*}$ & - & & & \\
ANC & $-0.702^{*}$ & $-0.536^{*}$ & - & & \\
ANIE & $-0.381^{* *}$ & $-0.379^{* *}$ & $0.506^{*}$ & - & \\
BSD & $-0.680^{*}$ & $-0.691^{*}$ & $0.452^{*}$ & 0.053 & - \\
\hline
\end{tabular}

* Correlation is significant at the 0.01 level.

** Correlation is significant at the 0.05 level.

visualized at the light microscope as BSD in the earthworm chloragocytes. However, the individuals of the volcanically-active area, i.e., Furnas, presented a much higher BSD extent than the ones of the inactive volcanic area, i.e., Santa Maria. In fact, the BSD extent in the lysosomal compartment has been proposed as a metal exposure biomarker that reflects the levels of bioavailable metals in the environment (Soto \& Marigómez 1997; Soto et al. 1998b, 1999; Da Ros et al. 2000; Porte et al. 2001). According to a previous study, there is a higher bioavailability of zinc and cadmium in the soils of Furnas when compared with Santa Maria.

The principal biological effects observed in earthworms inhabiting in both areas were alterations in the radial thickness of the chloragogenous tissue and in the intestinal epithelium. The currently observed morphological alterations were strongly and negatively correlated to the BSD extent, and may be interpreted as an adaptation of the earthworms to the accumulation of bioavailable metals, meaning perhaps that high levels of metals may cause depletion of both tissues. Analogous adaptations in the digestive epithelium thickness of mollusks have been previously reported as an effect of changes in environmental quality as increased bioavailability of pollutants (Lowe et al. 1981; Vega et al. 1989; Marigómez et al. 1990, 1991, 1992; Cajaraville et al. 1992). Marigómez et al. $(1996,1997)$ also found a clear evidence of severe adaptative changes in the digestive gland of mollusks following long-term/ chronic exposure to pollutants. According to Morgan et al. (2002), the earthworm chloragocyte suffers morphological alterations to cope with larger quantities of metals.

The TUNEL-test showed that DNA fragmentation, which is a marker of apoptosis, was occurring in both chloragogenous tissue and intestinal epithelium and exclusively in the individuals of Furnas, where the mean radial thickness of both tissues was lower, possibly induced by the higher levels of BSD extent found in those. This way, the high levels of BSD extent in Furnas may correspond to high bioavailability of metals that stressed the cells of the intestinal epithelium but especially of the chloragogenous tissue and provoked apoptosis, that lead to a depletion and consequent regeneration of both tissues. Like a variety of environmental organic and inorganic chemical stressors that can produce qualitative and quantitative changes in the chloragocytes 
(Ireland \& Richards 1977; Fischer \& Molnar 1992; Vogel and Seifert 1992), metals such as zinc and cadmium may have apoptotic and/or necrotic effects over cells of different organs (Seve et al. 2002; Hwang et al. 2004). In vivo data suggests that zincinduced oxidative stress may result in apoptosis, leading to a reduction in neurons in the substantia nigra, followed by reduced dopaminergic function in the nigrostriatal dopaminergic system (Lin et al. 2003). A study of Hwang et al. (2004) on planarian apoptosis shows that this mechanism can occur in normal conditions and in regenerating parts of the body of the planarian. Fischer and Molnar (1992) found an almost total depletion of the chloragogenous tissue in paraquat toxicated earthworm Eisenia fetida, and Fischer (1989) also found that when the worms were put in untoxicated medium the chloragogenous tissue renewed itself. Thus, the depletion of the chloragogenous tissue found in this study might be explained by an augmented rate of turnover of chloragocytes related with an increased apoptotic cell death (Vogel \& Seifert 1992), and perhaps a higher rate of chloragocyteeleocyte transformation (Fischer 1989; Fischer \& Molnar 1992) since Cancio et al. (1995) suggests that an extrusion of whole chloragocyte may occur as a way of eliminating toxic metals.

One may conclude that the volcanic environment poses stress to organisms that inhabit areas volcanically active forcing them to adapt by changing their rates of programmed cell death and consequently the morphometric characters of some of their organs, such as the chloragogenous tissue. Thus, the quantitation of the observed morphological changes and of the apoptotic nuclei, especially in the chloragogenous tissue, can be used as a reliable biomarker of effect to bioavailable metals in natural populations of $L$. $t$. inhabiting active volcanic environments.

\section{Acknowledgements}

The authors thank Dr. V. Carneiro, from the Hospital do Divino Espírito Santo, for imaging assistance and comments. This study was financially supported by Centro de Investigação de Recursos Naturais (CIRN), University of the Azores. AFS Amaral was supported by a $\mathrm{PhD}$ grant from Fundação para a Ciência e a Tecnologia (SFRH/ $\mathrm{BD} / 8186 / 2002)$.

\section{References}

Cajaraville MP, Marigómez JA, Díez G, Angulo E. 1992 Comparative effects of the water accommodated fraction of three oils on mussels.2. Quantitative alterations in the structure of the digestive tubules. Comp Biochem Physiol 102C, 113-123.

Calevro F, Campani M, Bucci S, Mancino G. 1998 Tests of toxicity and teratogenicity in biphasic vertebrates treated with heavy metals $\left(\mathrm{Cr}^{3+}, \mathrm{Al}^{3+}, \mathrm{Cd}^{2+}\right)$. Chemosphere 37(1415), 3011-3017.

Cancio I, ap Gwynn I, Ireland MP, Cajaraville MP. 1995 The effect of sublethal exposure on the ultrastructure and on the distribution of acid phosphatase activity in chloragocytes of earthworms (Annelida, Oligochaeta). Histochem J 27, 965973.

Da Ros L, Nasci C, Marigómez I, Soto M. 2000 Biomarkers and trace metals in the digestive gland of indigenous and transplanted mussels, Mytilus galloprovincialis, in Venice Lagoon, Italy. Mar Environ Res 50, 417-423.

Danscher G. 1984 Autometallography. A new technique for light and electron microscopic visualization of metals in biological tissues (gold, silver, metal sulphides and metal selenides). Histochemistry 81, 331-335.

Feraud G, Schinke H-U, Lietz J, Gostaud J, Pritchard G, Bleil U. 1984 New K-Ar ages, chemical analyses and magnetic data of rocks from the islands of Santa Maria (Azores), Porto Santo and Madeira (Madeira archipelago) and Gran Canaria (Canary islands). Arquipélago, Ciências da Natureza 5, 213-240.

Ferreira T, Oskarsson N. 1999 Chemistry and isotopic composition of fumarole discharges of Furnas caldera. $J$ Volcanol Geotherm Res 92, 179-179.

Filipic M, Hei TM. 2004 Mutagenicity of cadmium in mammalian cells: implication of oxidative DNA damage. Mutat Res-Rev Mutat Res 546, 81-91.

Fischer E. 1989 Effects of atrazine and paraquat-containing herbicides on Eisenia foetida (Annelida, Oligochaeta). Zoologischer Anzeiger 223(5/6), 291-300.

Fischer E, Molnar L. 1992 Environmental aspects of the chloragogenous tissue of earthworms. Soil Biol Biochem 24(12), 1723-1727.

Guest JE, Gaspar JL, Cole PD, Queiroz G, Duncan AM, Wallenstein N, Ferreira T, Pacheco J-M. 1999 Volcanic geology of Furnas Volcano, São Miguel, Azores. J Volcanol Geotherm Res 92, 1-29.

Hei TM, Filipic M. 2004 Role of oxidative damage in the genotoxicity of arsenic. Free Radic Biol Med 37(5), 574-581.

Hemelraad J, Herwig HJ. 1988 Cadmium kinetics in freshwater clams. IV. Histochemical localization of cadmium in Anodonta cygnea and Anodonta anatina exposed to cadmium chloride. Arch Environ Contam Toxicol 17, 337-343.

Holwerda DA. 1991 Cadmium kinetics in freshwater clams. V. Cadmium-copper interaction in metal accumulation by Anodonta cygnea and characterization of the metal-binding protein. Arch Environ Contam Toxicol 21, 432-437.

Hopwood D. 1996 Fixation and fixatives. In: Bancroft JD, Stevens A, eds. Theory and Practice of Histological Techniques, 4th edition. Hong Kong: Churchill Livingstone; 23-46.

Hwang JS, Kobayashi C, Agata K, Ikeo K, Gojobori T. 2004 Detection of apoptosis during planarian regeneration by the expression of apoptosis-related genes and TUNEL assay. Gene 333, 15-25. 
Ireland M. 1977 Heavy worms. New Sci 76(1079), 486-487.

Ireland MP, Richards KS. 1977 The occurrence and localisation of heavy metals and glycogen in the earthworms Lumbricus rubellus and Dendrobaena rubida from a heavy metal site. Histochemistry 51, 153-166.

Jamieson BGM. 1992 Oligochaeta. In: Harrison FW, Gardiner SL, eds. Microscopic Anatomy of Invertebrates, Vol 7, Annelida. New York: Wiley-Liss Inc,; 217-322.

Kelepertsis A, Alexakis D, Kita I. 2001 Environmental geochemistry of soils and waters of Susaki area, Korinthos, Greece. Environ Geochem Health 23(2), 117-135.

Kerr JFR. 2002 History of the events leading to the formulation of the apoptosis concept. Toxicology 181182, 471-474.

Krug HF. 2002 Metals in clinical medicine: the induction of apoptosis by metal compounds. Mat.-wiss. u. Werkstofftech 33, 770-774.

Langdon CJ, Piearce TG, Black S, Semple KT. 1999 Resistance to arsenic-toxicity in a population of the earthworm Lumbricus rubellus. Soil Biol Biochem 31, 1963-1967.

Langdon CJ, Piearce TG, Meharg AA, Semple KT. 2001 Resistance to copper toxicity in populations of the earthworms Lumbricus rubellus and Dendrodrilus rubidus from contaminated mine wastes. Environ Toxicol Chem 20(10), 2336-2341.

Lin AMY, Fan SF, Yang DM, Hsu LL, Yang HJ. 2003 Zincinduced apoptosis in substantia nigra of rat brain: neuroprotection by vitamin D3. Free Radic Biol Med 34(11), 14161425.

Lowe DM, Moore MN, Clarke KR. 1981 Effects of oil in the digestive cells in mussels: quantitative alterations in cellular and lysosomal structures. Aquat Toxicol 1, 213-226.

Marigómez I, Kortabitarte M, Dussart GBJ. 1997 Tissue-level biomarkers in sentinel slugs as cost-effective tools to assess metal pollution in soils. Arch Environ Contam Toxicol 34, $167-176$.

Marigómez I, Sáez V, Cajaraville MP, Angulo E. 1990 A planimetric study of the mean epithelial thickness (MET) of the molluscan digestive gland over the tidal cycle and under environmental stress conditions. Helgolander Meeresuntersuchungen 44, 81-94.

Marigómez I, Soto M, Angulo E. 1991 Responses of winkles digestive cells and their lysosomal system to environmental salinity changes. Cell Mol Biol 37, 29-39.

Marigómez I, Soto M, Angulo E. 1992 Seasonal variability in the quantitative structure of the digestive tubules of Littorina littorea. Aquat Living Resour 5, 299-305.

Marigómez I, Soto M, Kortabitarte M. 1996 Tissue level biomarkers of biological effect of mercury on sentinel slugs, Arion ater. Arch Environ Contam Toxicol 31, 54-62.

Martoja R, Martoja-Pierson M. 1970 Técnicas de Histología Animal. Barcelona: Toray Masson S.A.

Morgan JE, Morgan AJ. 1989 Zinc sequestration by earthworm (Annelida: Oligochaeta) chloragocytes. An in vivo investigation using fully quantitative electron probe X-ray micro-analysis. Histochemistry 90(5), 405-411.

Morgan AJ, Turner MP, Morgan JE. 2002 Morphological plasticity in metal-sequestering earthworm chloragocytes: morphometric electron microscopy provides a biomarker of exposure in field populations. Environ Toxicol Chem 21(3), 610-618.

Nunes JC, Carvalho MR, Forjaz VH. 1993 Short note on São Miguel Island (Azores) tiltmeters. Acoreana 7(4), 633-641.

Porte C, Sole M, Borgi V, Martinez M, Chamorro J, Torreblanca A, Ortiz-Zarragoitia M, Orbea A, Soto M, Cajaraville MP. 2001 Chemical, biochemical and cellular responses in digestive gland of mussels Mytilus galloprovincialis from the Spanish Mediterranean coast. Biomarkers 6, 335-350.

Seve M, Chimienti F, Favier A. 2002 Rôle du zinc intracellulaire dans la mort cellulaire programmée. Pathol Biol 50, 212-221.

Soto M, Cajaraville MP, Angulo E, Marigómez I. 1996 Autometallographic localization of protein-bound copper and zinc in the common winkle, Littorina littorea: a light microscopical study. Histochem $J$ 28, 689-701.

Soto M, Lekube X, Marigómez I. 1999 Discrete localisation of $\mathrm{Cu}$ and $\mathrm{Zn}$ within target cell compartments of winkles on exposure to $\mathrm{Cu} \& \mathrm{Zn}$ mixtures: an autometallographical study at the light-microscope. Eur J Histochem 43, 323-334.

Soto M, Marigómez I. 1997 Metal bioavailability assessment in 'mussel-watch' programmes by automated image analysis of autometallographical black silver deposits (BSD) in digestive cell lysosomes. Mar Ecol-Prog Ser 156, 141-150.

Soto M, Quincoces I, Lekube X, Marigómez I. 1998b Autometallographed metal content in digestive cells of winkles: a cost-effective screening tool to monitor $\mathrm{Cu}$ and Zn pollution. Aquat Toxicol 40, 123-140.

Soto M, Quincoces I, Marigómez I. 1998a Autometallographical procedure for the localization of metal traces in molluscan tissues by light microscopy. J Histotechnol 21, 123-127.

Stürzenbaum SR, Kille P, Morgan AJ. 1998 The identification, cloning and charaterization of the earthworm metallothionein. FEBS Lett 431, 437-442.

Vega MM, Marigómez I, Angulo E. 1989 Quantitative alterations in digestive cell structure of the marine gastropod Littorina littorea on exposure to cadmium. Mar Biol 103, 547-553.

Vogel J, Seifert G. 1992 Histological changes in the chloragogen tissue of the earthworm Eisenia fetida after administration of sublethal concentrations of different fluorides. $J$ Invertebr Pathol 60, 192-196.

Waalkes MP. 2003 Cadmium carcinogenesis. Mutat Res-Rev Mutat Res 533, 107-120.

Waisberg M, Joseph P, Hale B, Beyersmann D. 2003 Molecular and cellular mechanisms of cadmium carcinogenesis. Toxicology 192, 95-117.

Zhang J, Xu M. 2002 Apoptotic DNA fragmentation and tissue homeostasis. Trends Cell Biol 12(2), 84-89. 